\title{
A narrative case study of Indonesian EFL learners' identities
}

\author{
Yanty Wirza \\ Department of English Education, Faculty of Language and Literature Education, Universitas Pendidikan Indonesia, \\ Bandung, West Java, Indonesia
}

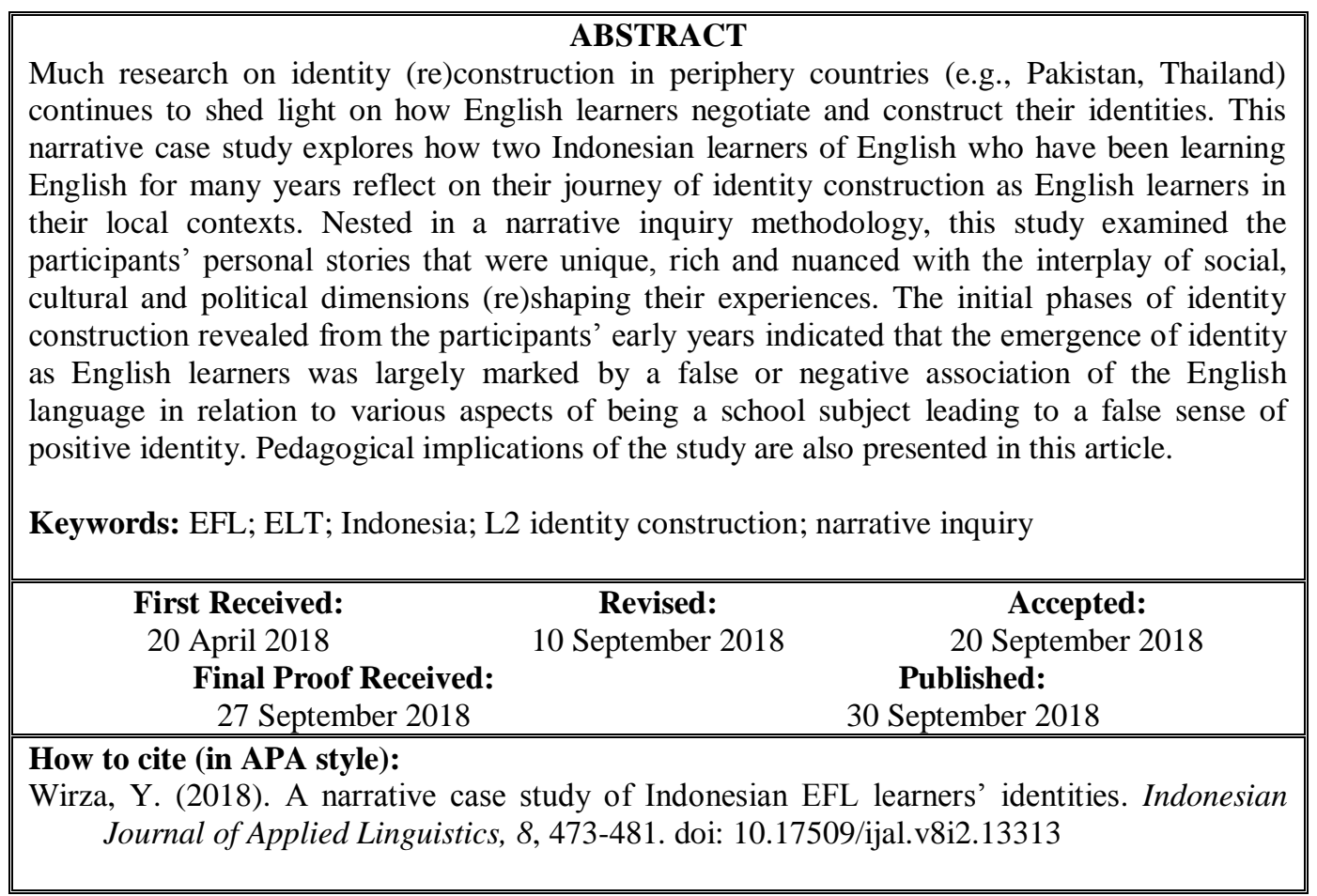

\section{INTRODUCTION}

Identity serves as a way of relating oneself to the world (van Lier, 2007). Research on identity continues to capture the attention of scholars and has been a scholarly debate and conversation in the area of L2 research during the last few decades (e.g., Block, 2007; 2009; Gee, 2001; Lie \& Liu, 2018; Norton Peirce, 1995; Norton, 2000; 2007; 2013; Norton \& De Costa, 2018). A recent meta-analytical review by Lie and Liu (2018) indicates that identity is one of the most widely researched topics in the field of applied linguistics in the past decade. The notion of identity lies in the interconnection between learners and their sociocultural world inherently subjective, contested, and changing in nature (Gee, 2001). In Norton's (2000) term, the process of identity construction is "the site of struggles ... multiple, and contradictory" (p.127). As Gee (2007) points out, in reality, no one speaks a single and uniform language; thus, no one possesses a single and uniform identity. Thus, individuals have "multiple whos (we are) and whats (we are doing)" (p. 93) that they construct on an on-going basis (Kumaradivelu, 2012). Thus, identity is "a way of talking about how learning changes who we are and creates personal histories of becoming in the contexts of communities" (Wenger, 1998, p. 5).

Norton and De Costa (2018) has recently noted that while there has been a growing interest in researching and developing theories of identity in language learning and teaching, the field needs to push further to better understand how identity plays out in a fast changing, exciting but unequal social world. EFL learners from periphery countries (e.g., Indonesia, Pakistan, Thailand) often find themselves in the constant struggles as to how they make sense of their learning experience and how learner identity impacts them as individuals (Widodo, 2017). Studies on identity construction and negotiation in several contexts (e.g., Indonesia, Thailand) often demonstrate the existing and on-going tensions for English learners in relation to their already complex existing identities (Duff, 2012). In the case of Singapore, the interconnection between English and the identity of its citizens was reported by Chew (1999) and $\mathrm{Ng}$ (2012) who found that the spread of English in Singapore is the conscious choice of 
Singaporeans who view its use as the key to their economic survival at the expense of losing their ethnic identity and Asian values.

In Bangladesh, Sultana's (2012) study showed that there have been prevailing concerns over the use of English by young Bangladeshi in their everyday conversations that would erode the sanctity of the Bangla language. Sung's (2014) study on the various expressions of Hong Kongese English learners' identity showed the participants' desire to construct a global identity as global citizens. In the context of China, a study by Gu (2010) reported the students' different discursive strategies for negotiating their English learner identities as they struggled to claim legitimacy. Moreover, Atay and Ece's (2009) study in Turkey found that the Turks' English L2 identity seemed to be culturally rooted in their Muslim and national identities as they embraced the broadening world view and ways of thinking of others of different cultures. In a longitudinal study of EFL identity development, Gao, Jia, and Zhou (2015) reported that over a four-year period of time, positive construction showed steady growth with varying degrees at different stages for individual learners that are indicative of the complexity and ambivalence of identity development. These studies show tensional liberatory and oppressive power of English (Alexander, 2003; Canagarajah, 2000); English learners are both victims and beneficiaries of the ideology of English as a global language (Gee, 2010).

In the Indonesian context, scanty research has been done to explore how Indonesian EFL learners construct their identity in the existing socio-political and cultural situations. Generally, previous studies have shown that ELT in Indonesia face numerous and serious challenges concerning low teachers qualifications, students' motivation, quality of textbooks, bureaucrats' attitudes, and government policies (Alwasilah, 2001; World Bank, 2010), and prescriptive curricula that "do not recognize crucial elements of what the curriculum means to English teachers, school administrators, teacher educators, and interested stakeholders" (Widodo, 2016, p. 139). Moreover, students only afforded limited exposure to and use of English in classrooms (Pasaribu, 2001; Widodo, 2017) and experienced English lessons with learning resource constraints in both quality and availability (Collins, 2006; Mattarima \& Hamdan, 2011). Some studies investigated the issues pertaining to the roles and functions of English for contemporary Indonesians. Haryanto, Sulistyo, Khairani, and Wulan (2016) examined student teachers' preferences of English over Indonesian to be used in the classroom. In the same vein, Silalahi (2016) found that English had become the need for being citizens in the globalized world. Lie (2017) in her recent review argued that English could enrich Indonesian identity formation as it expanded the students' knowledge and appreciation of their own culture as well as those of others. However, a very few studies have looked at the personal experiences of Indonesian EFL learners concerning English language learning experience.
Therefore, this study seeks to fill this gap by investigating the identity construction process performed by Indonesian EFL learners through their personal lived experiences. By so doing, it also contributes to the wealth of research in identity situated in periphery contexts (Norton \& De Costa, 2018). ELT situated in periphery contexts such as in Indonesia reflects "the formalities of an educational institution and embodied more or less explicitly in the learning aims and objectives attributed to the institution by governments at local or national levels" (Byram, 2009, pp. 6-7). As a result, the use of English in EFL contexts is very restricted to classroom use and rarely used as a means of communication in naturalistic settings because English is not the dominant language in society (Doro, 2007; Manchon, 2008). In a larger society context, English proficiency is considered as high status knowledge (Apple, 1990); this means that only a small number of people could have access and opportunities to learn and to be proficient in English. However, for most Indonesian EFL learners, often time, the only access they have is through the limited instructional hours in the classroom where meaningful linguistic and discursive practices rarely occur. Given this circumstance, it is arguably significant to listen to these learners' voices and experiences of how they cope with the situation and construct and negotiate their EFL identity while learning English.

\section{METHOD}

One of the most profound ways to examine identity construction is through individuals' narratives. As a research methodology, a narrative inquiry design is used to look into one's lived experience (Clandinin \& Connelly, 2000; Clandinin \& Rosiek, 2007) so as to understand one's lived realities and his/her social settings in which they were (re)constructed. This design allows the present study to closely explore participants' construction of identity through their lived experiences in learning and using English influenced and shaped by social, cultural, and political discourses in which they performed their English learning chores.

Two participants, Agus and Hapsari (male and female, pseudonyms), were recruited in this study. Both came from humble family background. Although the two participants are the Javanese, they speak different dialects of Javanese. Agus grew up in Tegal, Central Java and speaks the Tegalese dialect of Javanese in his familial environment. Hapsari grew up in a village in Tuban, East Java and speaks the Tubanese variety of Javanese. In fact, in the provinces on Java Island where Javanese and its varieties serve as local vernaculars, they are taught in elementary and junior high schools as a local content subject (Widodo \& Fardhani, 2011). In elementary school, Agus learned Indonesian (Bahasa Indonesia) as a medium of instruction. He was also exposed to Arabic as he studied at Pesantren (Islamic school) for his elementary and middle schooling. Hapsari joined regular public schools. Like Agus, she 
also learned and used Bahasa Indonesia for educational purposes and to communicate with other Indonesians who do not share the same linguistic backgrounds.
Table 1 presents the participants' demographic information.

Table 1. Participants' demographic information

\begin{tabular}{|c|c|c|c|c|c|c|}
\hline Name & Gender & Age & $\begin{array}{c}\text { Linguistic } \\
\text { Background }\end{array}$ & $\begin{array}{l}\text { Educational } \\
\text { Background }\end{array}$ & $\begin{array}{l}\text { Length of English } \\
\text { learning experience } \\
\text { (approx.) }\end{array}$ & $\begin{array}{c}\text { Socio-economic } \\
\text { backgrounds }\end{array}$ \\
\hline Agus & Male & 37 & $\begin{array}{l}\text { Javanese } \\
\text { (Tegalese dialect), } \\
\text { Indonesian } \\
\text { Arabic } \\
\text { English }\end{array}$ & $\begin{array}{l}\text { Post graduate } \\
\text { studies }\end{array}$ & 25 years & $\begin{array}{c}\text { Low socio- } \\
\text { economic status }\end{array}$ \\
\hline Hapsari & Female & 30 & $\begin{array}{l}\text { Javanese } \\
\text { (Tubanese dialect) } \\
\text { Indonesian }\end{array}$ & $\begin{array}{l}\text { Post graduate } \\
\text { studies }\end{array}$ & 18 years & $\begin{array}{l}\text { Low socio- } \\
\text { economic status }\end{array}$ \\
\hline
\end{tabular}

This study spanned over eight months of data gathering in an intimate and collegial environment that is crucial for building rapport and trust between the researched and researchers. The participants and the researcher participated in the same Indonesian Government-sponsored postgraduate program in the 2014-2015 academic year at the same US university where we interacted with each other and met on a regular basis. Data were collected through in-depth interviews lasting an hour each session in which the participants shared their detailed and nuanced experiences in learning English in their local contexts. Each of the participants was interviewed three times where they narrated their lived experiences of being EFL learners. They were asked to recount their initial encounters with English that covered the contexts and situations as well as the illustrations of events and people involved in particular events. For instance, they were asked to describe when the first time they learned English, who taught them, how their teachers taught English, and what the participants did during English lessons.

Other questions required the participants to reflect on their experience by asking whether they liked the English language, enjoyed learning the language, and encountered the experience that motivated and challenged and motivated the participants. The interviews were set up in a friendly, and confortable situation at the participants' apartment where it would be convenient for them. These interview sessions were conducted in Bahasa Indonesia to give the participants the opportunity to fully express themselves. The general impression I got during the interviews was that the participants seemed relaxed and genuine in sharing their personal stories.

The interview data were transcribed and listened to repeatedly through close, selective, and analytical listening (see Widodo, 2014) to comprehensively capture the message or meanings presented in the interview texts. For the data analysis, this study approached the data as a bottom-up, inductive and emergent process from the data in order to find emerging themes by way of employing several levels of coding while analyzing the data to find relevant events, experiences, and expressions to construct the themes. This thematic analysis (Riessman, 2003) used in this study emphasizes "what" is said more than "how" it is said, the "told" rather than the "telling." Put differently, the focus of the analysis is on the content of the story rather than on the linguistic features of the utterances. In this experience-centered narrative study (Squire, Andrews, Davis, Esin, Harrison, Hyden, \& Hyden, 2014), participants' stories were examined across the stories. I went forward and backwards across time in varying degrees of specificities, which sometimes led to other-related topics (Riessman, 2003). Within this framework, I showed the identity construction in relation to time and space from the early encounter and progression toward the future as the participants' lives unfolded.

\section{FINDINGS}

The study examined the participants' early identity construction as English language learners. The emergence of identity as a socio-culturally fluid concept rooted in this study is based on the emergence principle of identity construction proposed by Bucholtz and Hall (2010) as one of the key principles of analyzing identity construction. It is argued that identity is not a preexisting entity prior to discursive exposure to language. The initial encounters with English as a compulsory school subject for the participants were in junior high school. This means that English was not introduced by choice or preference; it was imposed on them through the school curriculum. In other words, there was no or little relevance for them to learn English, given the fact that they did not see English being used in their community. These participants recounted that they had no or little knowledge of English as a language prior to learning the language as a mandatory subject in junior high school. Presented below are the participants' accounts that portray the construction of their identities as English learners. 


\section{Agus:}

Agus' journey of identity construction started when he was first exposed to English in the first year of middle school at a pesantren (Islamic boarding school). In this context, English was introduced to Agus as a mandatory school subject as spelled out in the state curriculum. Pesantrens have similar grade levels to those of regular public schools. The striking difference between pesantrens (Islamic schools) and public schools is that Islamic schools have an extended curriculum as they put more emphasis on Islamic subjects. They abide by the Islamic rules and principles that govern the codes of conducts that regulate the students' and teachers' behaviors and interactions. Moreover, Agus grew up in the strong Islamic family environment that influenced and shaped his identities from an early age.

In the pesantren, Agus studied Arabic before he learned English. The presence of Arabic in his social surroundings and his education had a significant influence on his emergent identity as an EFL learner. Arabic was also taught as a foreign language, meaning that Arabic was not spoken as a means of communication in his society. It was used mainly for performing religious rituals and activities. With regard to identity construction, Agus had multiple language identities as a multilingual. Agus's first language was Javanese. He learned the Tubanese dialect of Javanese. Then, he acquired Bahasa Indonesia as his second social language. When Agus began his pesantren schooling, he learned Arabic, the language of instruction in Islamic schools. Before learning English, Agus acquired three social languages: Javanese, Bahasa Indonesia, and Arabic. Thus, learning English constructed Agus' already complex multiple language identities. $\mathrm{He}$ recounted:

I have an Arabic language background because my family had a pesantren. My elementary and middle schools were in this pesantren. I grew up and I've lived in the society with a strong Islamic background. When I grew up, I learned Arabic intensively, and I could read the Qur'an fluently. In some ways, my English was influenced by my Arabic background.

Agus' recount of the influence of Arabic on his English was intriguing. As he described, prior to learning English, Agus had already had an intensive Arabic learning experience. In the pesantren setting, the study of Arabic placed strong emphasis as it is the language to understand the Qur'an and other Islamic texts, such as Hadith. The study of Arabic to read and understand the Qur'an in this context typically would involve some levels of language mastery in terms of grammar and vocabulary as well as an understanding of the contexts of Arabic use for proper religious practices. Normally, rote learning, such as heavy reliance on drilling, memorization, and recitation was a common instructional practice or "ritual." The teaching of English was taught with the same methodology as that of Arabic inasmuch as pesantrens typically adopt traditional and top-down teaching and learning methods that rely heavily on rote learning. It seems plausible that Agus transferred his strategies for learning Arabic into learning English, and his existing identity as an Arabic learner was facilitative to his newly acclaimed identity as an English learner.

When he was almost done with his secondary schooling, Agus was thinking of continuing his education into university located in his province. He considered that his mastery of English in high school was a great asset to distinguish him from the rest of the applicants, so he majored in English Education at a local university in which he went through a merit-based admission process. He was successfully admitted into the program. At this point, Agus' identity as an English learner and user was validated, and he had much hope for success during his college years. As Agus recounted,

In middle school, I was excellent in (English) grammar and structure. So I had good grades on the exam. Because of the (good) grades, I was a high achiever in high school. I was also admitted into university through a special merit-based admission process called PMDK.

However, the firm confidence and positive identity Agus had developed over the years in his English learning in middle school suddenly plummeted when he took courses given by lecturers from Canada and Australia. To his surprise, he could not understand the lectures presented to him and his classmates. As Agus narrated,

In the first year of college, (we had) professors who were from Canada and Aussie [sic]. And when they spoke English, I was confused. I didn't understand at all (what they were talking about).

The above excerpt shows the state of discomfort and anxiety Agus must have felt about his presumed ability in English. As he described, his good grades and knowledge about English grammar and structure did not help him understand the lectures given by some of the lecturers who were native speakers of English. The struggle to understand the lectures in English and the low GPA in the first year of college had shaken his identities as a successful English language learner. Agus' initial positive identity that he assumed for years turned out to be a false positive identity. Agus was forced to learn that English as he had known in high school could not enable him to understand other speakers of English. He came to realize that he needed to reassess his previous learning experience and achievements.

The experience of interacting with other speakers of English from other countries had also opened Agus's eyes of different varieties of English being used. Apparently, despite his inability to comprehend the lectures, Agus managed to see the representation of 
imagined communities he began to penetrate through the seemingly frustrating first encounters. Agus' struggles in the first year of college encouraged him to seriously learn English. It took some time, but he put much effort and slowly reconstructed his confidence in himself to be a good English learner and user. He thought that his journey with English had taken him so far, and he did not want to give up. In his own words, Agus claimed that "I gave my all" which indicates his agency and investment to be successful in learning English in college. After two years, as a result, Agus could improve his English skills and increased his Grade Point Average (GPA) and confidence in using English with his professors and peers. Agus recounted that in the third year of college, he felt that he reclaimed a positive identity as an English learner and user.

\section{Hapsari:}

Hapsari started her initial encounters with English when she entered a public junior high school in Tuban, East Java Province, Indonesia. As she began to describe her journey as an EFL learner, Hapsari believed that she did not have previous exposure to English. As an English learner in a junior high school, she attended an English lesson unenthusiastically because of lack of familiarity and sense of relevance to the English language. As Hapsari recounted, one of the most significant aspects of English that was particularly new to her was English phonology; she felt English sounded different than Javanese or Bahasa Indonesia that she had acquired earlier in her life. Moreover, as she learned a few English vocabularies and simple expressions, she found that the English spellings and pronunciation sounded strange that she felt discouraged to actively participate in the teaching and learning activities. About her first encounters with English, Hapsari recalled:

I first learned English in junior high school. I had no idea about English in the elementary school. ...(in junior high school), I had no interest to speak and use English. I felt like I was very passive. English was like a strange kind of food in my mouth (laugh). ...I was not particularly motivated to learn English in high school because I was focusing my effort more on difficult subjects like math and science. I took the (extra) course in math.

In the above excerpt, Hapsari shared that her unfamiliarity with English' phonology and morphosyntax when she began to learn English in school had a caused negative impact on her participation in the learning process, leading to having a lack of interest and motivation to learn English. By a means of analogy, she likened it with having to eat a strange food. Her use of 'strange food' metaphor indicates the feeling of newness, but at the same time, evoking the feeling of discomfort and uneasiness. In other words, in her initial stages of English learning experiences, Hapsari developed negative associations with English, which in turn created a negative sense of identity as an EFL learner.

As shown in above excerpt, instead of putting much work on learning English, Hapsari invested more on math and science subjects. Math and science were traditionally perceived as "hard" subjects by which students' academic achievements and performance were measured. This perception led Hapsari to believe that English was not as important as mathematics and science. As a result, Hapsari might have built a more positive identity as a math and science learner but developed a negative identity as an EFL learner.

Moreover, when asked to describe the typical English lesson, Hapsari reported:

The teachers would tell us to memorize the tenses and vocabularies; what is a noun, what is a verb. A lot of grammar exercises. They taught English in the Indonesian language, but they modeled the dialogues in English, like, from the textbook. The themes we learned were families, daily activities, and school-related activities like homework and projects.

The English teaching and learning process Hapsari illustrated above clearly showed form-focused instruction with heavy memorization and drilling, commonly implemented in many Indonesian middle schools (Widodo, 2016). In such a teaching and learning situation, Hapsari could not motivate herself to enact more agency and investment in learning English. Having similar experiences until she finished the junior high school, Hapsari's EFL learner identity remained negative.

As Hapsari continued her studies into senior high school, she realized that her lack of agency and investment in learning English began to bring negative consequences for her overall academic performance. Regarding this experience, she reported:

When I was in senior high school, my grades were so low that I decided to enroll in a private course. Not long after enrolling in that course, my grades improved, I got an 8 in my grade book for English. Then, there were more intensive grammar exercises for the preparation for the Ebtanas (Exit Level National Evaluation), so this course helped me prepare for the exam.

Hapsari in the excerpt above reflected that in high school she realized the importance of English and decided to enroll in an English course to improve her English performance. Moreover, as English was one of the subjects tested on the final exit level examination for completing her high schooling, Hapsari was noticeably anxious about her performance in the examination. In this case, it is obvious that Hapsari's motivation to learn English was heavily associated with obtaining good grades and passing the examination. However, from 
Hapsari's standpoint, her enrollment in the private English course was her enactment of her agency and strategic investment to be a successful EFL learner. Achieving such instrumental goals as getting good grades and passing an examination is common among EFL learners. Thus, as far as achieving this "school success" was concerned, taking paid extra English lessons proved to serve Hapsari's goals as seen in her expression of joy upon her grades improvement. However, her identity as English learner and user at this point was mainly positive but remained instrumental.

In the second year of senior high school, a critical event took place that changed Hapsari's perception about English. In one of the classes of the private course she was taking, she was taught by Mr. Budi, who showed and convinced her that learning English could be exciting. Hapsari, initially taking and thinking of English as no more than grades, started to see English as a means of communication leading to more a genuine interest to learn subject.

I started to love English from this teacher. ...He used a lot of dialogues and he would never switch to Indonesian. To be honest, he made many grammatical mistakes in the sentences and his pronunciation was terribly inaccurate. I found out about all this when I learned more about English as a university student. I met him after some years and was surprised by his pronunciation. He would just guess how to pronounce the words - but refused to use Indonesian...no matter what (laugh). He would sound like he was very fluent in English, just like the way he spoke in Javanese or Indonesian.

Mr. Budi's determination to exclusively use English had fascinated Hapsari, who prior to taking lessons with him, had negative associations about English. Using dialogues and role plays, he had created a teaching and learning environment in which English served communicative functions, and not simply a set of rules and vocabulary to memorize. In addition, he set himself as an example to have full confidence in using English, to engage and participate actively in the learning activities without being worried to make mistakes. With this experience, Hapsari gradually diminished her anxiety and gained a more positive attitude toward English as she began enjoying using English for more genuine communicative purposes. In a relatively short time, Hapsari developed a sense of enjoyment of learning and ownership of English. As a result, through the interactions with $\mathrm{Mr}$. Budi, as problematic as it sounds, due to his ill-structured English use, Hapsari enacted a positive identity as an English learner and user.

\section{DISCUSSION AND CONCLUSION}

The findings of this study show that the formation of identity of the two Indonesian EFL learners was influenced by the sociolinguistic and political landscapes (e.g., Block, 2007; Block \& Corona, 2016; Gee, 2001; Norton, 2000; 2013; van Lier, 2007). The study has demonstrated through lived experiences of the participants how their identity as EFL learners was negotiated and transformed. From the socio-religious and cultural perspectives, Agus found Arabic being facilitative to the construction of his English identity at the early stage because he transferred his knowledge, practice, and study skills in learning Arabic into learning English. This indicates that the previous linguistic identities played a role in his identity formation (Gee, 2001). At the later stage, even though Agus had enacted a positive identity as EFL learner during his middle school years, his first encounter with native speakers of English in college shook his identity as he suddenly felt incompetent in English. Studies have reported similar phenomena where encounters with native speakers of English cause insecurity (Zacharias, 2012) and highlight asymmetrical NS/NNS power relations (Yeh, 2014). Other studies show that in their interaction with native speakers, the English learners also tend to perform in a less-than-fully confident manner (Yeh, 2013) and that the interaction typically does not progress beyond small talks (Ortactepe, 2013).

Hapsari shared a different story. Her initial encounters with English were marked by deterred inclination due to lack of interests and motivation in learning it. Her experience indicates the impacts of motivation in learning and engagement (e.g., Lamb, 2017; 2009; Cresfield \& White, 2012; Waninge, Dörnyei, De Bot, 2014). Finding herself unmotivated to learn English, Hapsari struggled to construct a strong and positive EFL learner identity. At a later stage, the discursive practice with the private course teacher, Mr. Budi, became the turning point for Hapsari from a disfavor of and resistance to English to love and enjoyment. Mr. Budi had inspired her through his passion for English in his regular use of English in his teaching despite his poor grammar and pronunciation. This shows that a teacher could be a transformational force for learners to promote a positive English identity. In addition, this indicates that Indonesian EFL learners would like teachers to demonstrate the use of English in class (Haryanto, Sulistyo, Khairani, \& Wulan, 2016); however, studies show that English teachers tend to use Indonesian or local languages instead of English in English classrooms (Pasaribu, 2002; Ragawanti, 2007). From pedagogical perspectives, having little exposure to English will minimize opportunities for learners to have English discursive practices necessary to construct the identity as English learners and users.

From the perspective of language policy, English as a foreign language taught in schools and other educational institutions has important social, political and economic implications (Knapp, Seidlhofer, \& Widdowson, 2009). In this case, the position of English as a foreign language (Lauder, 2007) had a bearing on how the participants experienced the learning of English inside and outside school contexts. In Agus and 
Hapsari's stories, their struggles to deal with their situations are indicative of their agency and investment (Norton, 2000, 2013) to overcome the challenges. Their agency had been materialized through self-directed behaviors in their actions and decisions, and their assessment of the learning context (Mercer, 2011). Investment, on the other hand, is manifested in the efforts made, time spent, or resources utilized in learning processes.

The pedagogical implications can be drawn. As Agus and Hapsari's stories show, the EFL instruction they had in school was characterized by form-focused and teacher-centered instruction emphasizing frequent occurrences of high-frequency words, simple grammar, repetition, and memorization (Doro, 2007). This instruction tends to demotivate students to actively engage in the learning process. Admittedly, for EFL teachers, one of the most pressing challenges is to increase learners' motivation to learn (Alwasilah, 2001; Dornyei, 2001). On the other hand, we have also learned how Hapsari was highly motivated to learn English from her private course instructor. This indicates the critical role of teachers in motivating (or demotivating) learners to learn English. Obviously, this is not to say that teachers' effort to enhance learners' motivation could be done without paying attention to their pedagogical competencies. In fact, teachers should comprehensively acquire content and pedagogical knowledge and skills necessary to craft motivating learning instruction.

Finally, the study has contributed to a fuller understanding of how Indonesian English learners constructed complex and multiple identities situated in an EFL periphery context. Enacting and negotiating multiple identities in an increasingly globalized world are inevitable (Darvin \& Norton, 2015), and as the globalization penetrates deeply into the lives of most Indonesians, English could "provide a bridge to explore the wider world and reflect on our own identit[ies]" (Lie, 2017, p.85). Given the importance of identity in the learners' journey as EFL learners and users, future research is needed to investigate identity construction in other periphery contexts. Learners' stories and voices are a catalyst for language teachers and curriculum designers to inform their teaching and curriculum practices. Further studies in identity in periphery contexts could also use critical lenses and other research methodologies such as ethnography and phenomenology to examine EFL learners' identity in relation to larger social practices.

\section{REFERENCES}

Alexander, R. J. (2003). G.lobal l.anguages o.ppress b.ut a.re liberating, too: The dialectics of English. In C. Mair (Ed.), The politics of English as a world language: New horizons in postcolonial cultural studies (pp. 87-96). New York: Rodopi.
Alwasilah, C. A. (2001). Language, culture, and education: A portrait of contemporary Indonesia. Bandung, Indonesia: Adira.

Apple, M. W. (1990). Ideology and curriculum (2nd edn). London: Routledge.

Block, D. (2007). The rise of identity in SLA research post Firth and Wagner (1997). Modern Language Journal, 91, 861-874. doi: 10.1111/j.15404781.2007.00674.x

Block, D., \& Corona, V. (2016). Intersectionality in language and identity research. In S. Preece (Ed.), The Routledge handbook of language and identity (pp. 533-548). London: Routledge.

Bucholtz, M., \& Hall, K. (2010). Locating identity in language. In Carmen Llamas and Dominic Watt (Eds.), Language and identities (pp. 18-28). Edinburgh: Edinburgh University Press.

Canagarajah, S. (1999). Resisting linguistic imperialism in English teaching. Oxford: Oxford University Press.

Canagarajah, S. (2000). Negotiating ideologies through English: Strategies from the periphery. In T. Ricento (Ed.), Ideologies, politics and language policies: Focus on English (pp. 121-132). Amsterdam: John Benjamins.

Clandinin, D. J., \& Connelly, F. M. (2000). Narrative inquiry: Experience and story in qualitative research. San Francisco, CA: Jossey-Bass.

Clandinin, D. J., \& Rosiek, J. (2007). Mapping the landscape of narrative inquiry: Borderlands spaces and tensions. In D. J. Clandinin (Ed.), Handbook of narrative inquiry: Mapping a methodology (pp. 35-76). Thousand Oaks, CA: Sage.

Collins, P. (2006). Grammar in TEFL: A critique of Indonesian high school textbooks. TEFLIN Journal, 17(1), 1-10.

Cresfield, E., \& White, J. (2012). Motivation research and SLA: Bringing it into the classroom. In M. Pawlak (Ed.), New perspectives on individual differences in language learning and teaching (pp. 217-232). New York: Springer.

Darvin, R., \& Norton, B. (2015). Identity and a model of investment in applied linguistics. Annual Review of Applied Linguistics, 35, 36-56. doi: 10.1017/S0267190514000191

Dörnyei, Z. (2001). New themes and approaches in second language motivation research. Annual Review of Applied Linguistics, 21, 43-59. doi: $10.1017 / \mathrm{S} 0267190501000034$

Doro, K. (2007). The use of high- and low-frequency verbs in English native and non-native student writing. In Z. Lengyel \& J. Navracsics (Eds.), Seco nd language lexical processes: Applied linguistic and psycholinguistic perspectives (pp. 117-132). Clevedon: Multilingual Matters.

Duff. P.A. (2012). Second language acquisition. In E. Ochs \& B. Schiffelin (Eds. ), The handbook of language socialization (pp. 564-586). West Sussex: Wiley-Blackwell. 
Gao, Y., Jia, Z., \& Zhou, Y. (2015). EFL learning and identity development: A longitudinal study in 5 universities in China. Journal of Language, Identity \& Education, 14(3), 137-158.

Gee, J. (2001). Identity as an analytic lens for research in education. Review of Research in Education, 25(1), 99-125.

Gee, J. (2007). Social linguistics and literacies: Ideology in discourses ( $3^{\text {rd }}$ edn.). London: Routledge.

Gu, M. M. (2010). Identities constructed in difference: English language learners in China. Journal of Pragmatics, 42(1), 139-152.

Haryanto, E., Sulistyo. U., Khairani, M., \& Wulan, R. (2016). Indonesian or English? EFL student teachers' preference and perception on the language use in the classroom. Indonesian Journal of English Education, 3(1), 46-59.

Knapp, K., Seidlhofer, B., \& Widdowson, H. (2009). Introduction: Developing foreign language communication: Principles and practices. In K. Knapp \& B. Seidlhofer (Eds.), Handbook of foreign language communication and learning (pp. 1-20). Berlin: Walter de Gruyter GmbH \& Co. KG.

Kumaravadivelu, B. (2012). Individual identity, cultural globalization, and teaching English as an international language: The case for an epistemic break. In L. Asalgoff, S., G. Hu, \& W. A. Renandya (Eds.), Principles and practices for teaching English as an international language (pp. 9-27). London: Routledge.

Lamb, M. (2009). Situating the L2 self: Two Indonesian school learners of English. In Z. Do“rnyei \& E. Ushioda (Eds.), Motivation, language identity and the L2 self (pp. 229-247). Clevedon, UK: Multilingual Matters.

Lamb, M. (2017). The motivational dimension of language teaching. Language Teaching, 50, 301346. doi: 10.1017/S0261444817000088

Lauder, A. (2008). The status and function of English in Indonesia: A review of key factors. Makara, Sosial Humaniora, 12(1), 9-20.

Lie, A. (2017). English and identity in multicultural contexts: Issues, challenges, and opportunities. TEFLIN Journal, 28 (1), 71-92.

Lie, L., \& Liu, D. (2018). Research trends in applied linguistics from 2005 to 2016: A bibliometric analysis and its implications. Applied Linguistics: Advance Online Publication. doi: 10.1093/applin/amy003

Manchon, R. S. (2008). Taking strategies to the foreign language classroom: Where are we now in theory and research. IRAL, 46(3), 221-243.

Mattarima, K., \& Hamdan, A. R. (2011). The teaching constraints of English as a foreign language in Indonesia: The context of school based curriculum. Sosiohumanika, 4(2), 287-300.

Mercer, S. (2011). Understanding learner agency as a complex dynamic system. System, 39, 427-436.
Ng, P. C. L (2012). English in the Singapore's Chinese community: Controversies, concerns and problems. Journal of English as an International Language, 7, 28-39.

Norton Pierce. B. (1995). Social identity, investment, and language learning. TESOL Quarterly, 29(1), 9-31.

Norton, B. (2000). Identity and language learning: Gender, ethnicity, and educational change. Harlow, England: Pearson Education.

Norton, B. (2013). Identity and language learning: Extending the conversation. Clevedon: Multilingual Matters.

Norton, B., \& De Costa, P. I. (2018). Research tasks on identity in language learning and teaching. Language Teaching, 51(1), 90-112. doi: $10.1017 / \mathrm{S} 0261444817000325$

Ortaçtepe, D. (2013). "This is called free-falling theory not culture shock!": A narrative inquiry on second language socialization. Journal of Language, Identity \& Education, 12, 215-229.

Pasaribu, B. (2001). The use of Bahasa Indonesia in the ELT classroom. TEFLIN Journal, 12(1), 142-148.

Ragawanti, D. T. (2007). Construction and obstruction of teacher explanation to the students learning: Perspectives of STIBA Satya Wacana students. TEFLIN Journal, 18 (1), 28-42.

Riessman, C.K (2003). Narrative analysis. In M. S. Lewis-Beck, A. Bryman, \& T. Futing Liao (Eds.), The Sage encyclopedia of social science research methods (pp.1-8). London: Sage.

Squire, C., Andrews, M., Davis, M., Esin, C., Harrison, B., Hyden, L. C., \& Hyden, M. (2014). What is narrative research? London: Bloomsbury Publishing.

Sultana, S. (2012). Problematizing the popular discourses about language and identity of young adults in Bangladesh. 3L: Language, Linguistics, Literature, 18, 49-63.

Sung, C. C. M. (2014). English as a lingua franca and global identities: Perspectives from four second language learners of English in Hong Kong. Linguistics and Education, 26, 31-39. doi: 10.1016/j.linged.2014.01.010

van Lier, L. (2007). Action-based teaching, autonomy and identity. Innovation in Language Learning and Teaching, 1 (1), 46-65.

Wenger, E. (2010). Communities of practice and social learning systems: The career of a concept. In Social learning systems and communities of practice (pp. 179-198). London: Springer.

Waninge, F., Dörnyei, Z., \& De Bot, K. (2014). Motivational dynamics in language learning: Change, stability, and context. The Modern Language Journal, 98(3), 704-723.

Widodo, H. P. (2014). Methodological considerations in interview data transcription. International Journal of Innovation in English Language Teaching and Research, 3 (1), 101-107. 
Widodo, H. P. (2016). Language policy in practice: Reframing the English language curriculum in the Indonesia secondary education sector. In Robert Kirkpatrick (Ed.). English language education policy in Asia (pp. 127-151). New York: Springer.

Widodo, H. P. (2017). Constructing and negotiating agency and identity of English language learners: Teacher-learner driven ESP materials development in the Indonesian secondary school context. Electronic Journal of Foreign Language Teaching, 14 (2), 233-249.

Widodo, H. P., \& Fardhani, A. E. (2011). The language rights of indigenous languages: An approach to maintaining Indonesia's linguistic and cultural diversity. In Quynh Le and Tnao Le (Eds.). Language diversity and cultural identity: A global perspective (pp. 129-140). New York: Nova Science.
World Bank. (2010). Transforming Indonesia's teaching force. Volume II: From pre-service training to retirement: Producing and maintaining a high-quality, efficient, and motivated workforce. Jakarta.

Yeh, L. M. (2013). World Englishes and identity construction: A qualitative analysis of two Taiwanese EFL undergraduates' viewpoints. The Asia-Pacific Education Researcher, 22(3), 327340.

Yeh, L. M. (2014). Participatory legitimacy in ESL practice and the use of coping strategies. Journal of Language, Identity \& Education, 13, 195-216.

Zacharias, N. T. (2012). EFL students' understanding of their multilingual English identities. Electronic Journal of Foreign Language Teaching, 9(2), 2337. 